International Journal of Automotive and Mechanical Engineering (IJAME)

ISSN: 2229-8649 (Print); ISSN: 2180-1606 (Online); Volume 8, pp. 1457-1466, July-December 2013

(OUniversiti Malaysia Pahang

DOI: http://dx.doi.org/10.15282/ijame.8.2013.32.0120

\title{
GASIFICATION OF COAL-PETCOKE BLENDS IN A PILOT SCALE GASIFICATION PLANT
}

\author{
N. Muda ${ }^{1^{*}}$ and M. H. Boosroh ${ }^{1}$ \\ Low Carbon Power Generation Technology Research Group \\ TNB research Sdn. Bhd. \\ No 1, Lorong Ayer Itam, Kawasan Institusi Penyelidikan, \\ 43000, Kajang, Selangor, Malaysia \\ Email: noraziah@tnbr.com.my \\ Phone: +603-89225036; Fax: +609-89268828
}

\begin{abstract}
This paper investigates the synergistic interaction in a gasification of coal and petcoke blends in a $150 \mathrm{~kW}_{\text {th }}$ pilot scale gasification plant. Petcoke was used either in combination with coal or separately to produce syngas in an atmospheric fluidized bed gasifier using air as gasifying agent. Syngas composition and carbon conversion efficiency were recorded and calculated. The results show that the increase in petcoke content in the fuel blend tends to lower the syngas composition. In addition, the carbon conversion efficiency also decreased with the increase in petcoke percentage in the blend. However, the conversion efficiency and syngas composition started to increase again when the petcoke percentage in the blend was more than $50 \%$. As far as the mixture of coal and petcoke is concerned, optimum gasification efficiency was obtained at a 90:10 coal:petcoke blend. The lowest heating value was observed when the mixture was at 50:50. Therefore this mixture needs to be avoided when gasifying the coal: petcoke blend because it has the minimum gasification efficiency.
\end{abstract}

Keywords: Gasification; carbon conversion efficiency; coal, petcoke; syngas.

\section{INTRODUCTION}

Coal is one of the biggest sources of power generation in Malaysia. However, it is also known that coal-fired power plants generate a lot of carbon dioxide $\left(\mathrm{CO}_{2}\right)$, which contributes to greenhouse gas (GHG) emissions. Considering the increasing demand for power, it is necessary to look for cleaner alternatives in coal-based power generation. The Integrated Gasification Combined Cycle (IGCC) is one of the potential technologies for clean coal power generation with high efficiency. IGCC has gained increasing attention in recent years as an alternative source of energy, largely because of rising oil and gas prices. IGCC is a process that turns carbon-containing material into synthesis gas (syngas). Syngas can be utilized for power generation as well as chemical feedstock. The systems combine a coal gasification unit with a gas-fired combined cycle power generation unit. The gasification process transforms coal into gases (mainly $\mathrm{CO}_{2}$, $\mathrm{CO}$ and $\mathrm{H}_{2}$ ), typically utilizing fluidized or moving bed reactors. Fluidized beds are known for their ability to handle a variety of feedstock such as coal, petcoke, biomass, plastic waste and others (Basu, 2006: Pinto et al., 2003; Mastellone, Zaccariello, and Arena, 2010; Taba et al., 2012; Daniele et al., 2013). Acceptance of the gasification of coal-based power generation technology is also increasing primarily due to its high efficiency and significantly reduced emissions of $\mathrm{NO}_{\mathrm{x}}, \mathrm{SO}_{\mathrm{x}}$ and particulates when 
compared with conventional coal-fired power station. IGCC systems offer emission levels approaching those of natural gas combined-cycle plants, with the low fuel cost of coal.

One of the advantages of gasification technology is that energy sources other than coal can be used as feedstock. This suggests investigating the possibility of feeding into the gasifier a combination of different fuels, since the possible synergy between their products and intermediates could help to maximize the process performance, thus reducing carbon losses and increasing the energy content of syngas (Mastellone et al., 2010). For example, petroleum coke or petcoke, which is an important by-product of petroleum refineries, was employed as feedstock in gasification systems, in combination with coal or separately, to produce a syngas (Nagpal, Sarakar, and Sen, 2005). Several experimental studies have been carried out using a mixture of feedstock, with coal, petcoke, biomass, plastic waste, and others (Pinto et al., 2005; Harris, Robert, \& Henderson, 2006; Fermonso et al., 2009; Li, Zhang, and Bi, 2010). Fermoso et al. (2009) studied the possible synergistic effect of coal-petcoke-biomass gasification using a steam/oxygen mixture as gasifying agent, at atmospheric and elevated pressure in a fixed bed reactor fitted with a solids feeding system in continuous mode. Interactions between the blend components were found to modify the gas production. An improvement in hydrogen production and cold gas efficiency was achieved when the coal was gasified with biomass. Lee et al. (2010) studied the gasification characteristics of petcoke and coal blends in an entrained flow gasifier and found that the syngas composition and calorific value were higher in the coal-petcoke mixture than in $100 \%$ petcoke. They suggested that co-gasification of petcoke and coal might be an excellent method to use lignite with high moisture content and petcoke with low reactivity because of its synergistic effect.

Previous studies in the literature concentrate on the separate gasification of both coal and petcoke, while systematic investigations on co-gasification of coal and petcoke in a fluidized bed are relatively few. Systematic study of the quality and quantity of syngas from coal-petcoke blends in a fluidized bed gasifier is scarce in the literature. Even though there are some studies on the gasification process of coal and petcoke, currently none of the study is carried out using fluidization by a gasifier. In this proposed study, gasification tests will be conducted using fuel blends of coal and petcoke to find their effect on the syngas composition and carbon conversion efficiency using a $30 \mathrm{~kW}_{\text {th }}$ lab scale atmospheric bubbling fluidized bed gasifier with air as the gasifying agent. Emphasis was put on the investigation of the producer gas composition and carbon conversion efficiency.

\section{METHODOLOGY}

\section{Feedstock}

In this work, sub bituminous coal (Adaro) was obtained from Manjung Power Station, Perak, while petcoke of the green type was obtained from PETRONAS Penapisan, Sungai Udang, Melaka. Four sample blends were prepared, namely at 90, 60, 50 and $70 \%$ coal. $100 \%$ each of coal and petcoke was also gasified as reference. The samples were ground and sieved to obtain a fraction with a particle size of around 500-600 $\mu \mathrm{m}$. Characterizations of feedstock were carried out systematically based on ASTM standard methods. The proximate analysis was used to measure inherent moisture content (MC), volatile matter (VM), fixed carbon (FC) and ash content (AC) in the fuels. The tests 
were carried out according to ASTM D5142-90 standard test methods using a thermogravimetric analyzer, model TGA/DTA 220U, SEIKO. The heating values of all fuel blends were determined according to the ASTM D 3286-96: Standard test method using an isoperibol bomb calorimeter, LECO AC-350. The elemental analysis of the organic fractions or ultimate analysis was carried out to determine the composition of carbon $(\mathrm{C})$, hydrogen $(\mathrm{H})$, nitrogen $(\mathrm{N})$, sulfur $(\mathrm{S})$ and oxygen $(\mathrm{O})$ according to two standard references which are i) ASTM D 5373-93: Standard test methods for instrumental determination of carbon, hydrogen and nitrogen in laboratory samples of coal and coke, and ii) ASTM D 4239-97: Standard test methods for sulfur in the analysis sample of coal and coke using high temperature tube furnace of combustion methods (method $\mathrm{C}$ - high temperature combustion method with infrared absorption procedure). Ultimate analysis was conducted using the LECO 3839 and Eltra CS500 instruments for determination of $\mathrm{CHN}$ and sulfur respectively. For the determination of proximate, ultimate and heating values, tests were carried out on the fuel blends and the $100 \%$ coal and $100 \%$ petcoke samples. The proximate and ultimate analyses and the high heating values of the samples are presented in Table 1.

Table 1. Proximate and ultimate analysis of coal and petcoke

\begin{tabular}{|c|c|c|c|c|c|c|c|}
\hline \multicolumn{2}{|c|}{ Coal:petcoke } & 100:0 & $90: 10$ & $60: 40$ & $50: 50$ & $30: 70$ & $0: 100$ \\
\hline \multirow{4}{*}{$\begin{array}{l}\text { Proximate } \\
\text { analysis (\%) }\end{array}$} & $\begin{array}{c}\text { Moisture } \\
(\%)\end{array}$ & 9.64 & 8.97 & 6.51 & 5.75 & 3.91 & 0.72 \\
\hline & $\begin{array}{c}\text { Volatile } \\
\text { matter }(\%)\end{array}$ & 45.79 & 41.80 & 31.40 & 28.30 & 21.25 & 1.06 \\
\hline & $\begin{array}{l}\text { Fixed } \\
\text { carbon }\end{array}$ & 42.83 & 47.27 & 60.66 & 64.62 & 73.76 & 87.96 \\
\hline & ash & 1.67 & 1.91 & 1.36 & 1.23 & 0.99 & 0.20 \\
\hline \multirow{5}{*}{$\begin{array}{l}\text { Ultimate } \\
\text { analysis }(\%)\end{array}$} & $\mathrm{C}$ & 71.00 & 73.30 & 76.55 & 84.60 & 90.50 & 99.60 \\
\hline & $\mathrm{H}$ & 5.49 & 5.37 & 4.29 & 5.65 & 6.06 & 6.14 \\
\hline & $\mathrm{N}$ & 0.93 & 0.29 & 0.99 & 0.54 & 0.75 & 0.57 \\
\hline & S & 0.11 & 0.66 & 2.51 & 3.12 & 4.15 & 5.68 \\
\hline & $\mathrm{O}^{*}$ & 20.80 & 18.48 & 13.79 & 4.80 & -2.44 & -12.18 \\
\hline$\overline{\mathrm{HV}}$ & $(\mathrm{MJ} / \mathrm{Kg})$ & 24.75 & 25.83 & 29.10 & 30.24 & 32.38 & 36.01 \\
\hline
\end{tabular}

From the result of the proximate analysis, it was found that the highest moisture content was observed in coal, and this gradually decreased with the introduction of petcoke in the fuel blends. Low moisture content of fuel is favorable in producing a better gaseous product (Basu, 2006). The fixed carbon content was found to be higher in petcoke than in coal, while the ash content was found to be lower in petcoke. The fixed carbon content is the carbon found in the material that is left after volatile materials are driven off. High fixed carbon and low ash content are important parameters in determining syngas composition and calorific value (Basu, 2006; Fermonso et al., 2009). Ultimate analyses for all fuels were analyzed by measuring the carbon, hydrogen, nitrogen and sulfur content. Table 1 shows that the carbon content in petcoke is the higher than in coal. This is in agreement with the result of fixed carbon content in the proximate analysis. However, carbon content differs from the fixed carbon content 
because some carbon is lost in hydrocarbons with the volatiles. The heating value of $100 \%$ petcoke was found to be the highest compared to the other feedstock (36.03 $\mathrm{MJ} / \mathrm{kg}$ ). The data of proximate, ultimate analysis and heating values indicate that approximately 36,030 MJ of petcoke energy can potentially be produced from 1 metric ton of petcoke with only $20 \mathrm{~kg}$ ash generated.

\section{Facility}

A simplified schematic of the $150 \mathrm{~kW}_{\text {th }}$ pilot scale gasification pilot plant is given in Figure 1. It is composed of 5 main sub systems; screw feeder for coal and petroleum samples, the reactor itself, blower, air heater, electric steam boiler, LPG burner, thermal camera, 2 pieces of cyclone, water scrubber, gas filter, induced fan and chimney. The reactor was constructed from stainless steel with a wall thickness of $10 \mathrm{~mm}$. It has the internal diameter of $350 \mathrm{~mm}$ and overall gasifier height of $3100 \mathrm{~mm}$. The experimental rig was set up to be operated at a fluidizing bed height of $700 \mathrm{~mm}$ and freeboard height of $2400 \mathrm{~mm}$. The bed operating temperature is $750-1000^{\circ} \mathrm{C}$ and bed pressure of 1 bar. The reactor was insulated with Kaowool to prevent heat loss through the wall. At the bottom of the reactor, an air distributor plate was installed for better air distribution. The distributor plate consisted of a plate with vertical nozzles and lateral perforation through which passes the air that is distributed uniformly into the main reactor. The vertical nozzles were used due to their convenience for high temperatures and their advantages of reducing the back flow of bed material towards the plenum. The plate diameter is 350 $\mathrm{mm}$ and plate thickness of $15 \mathrm{~mm}$. The orifice diameter is $3 \mathrm{~mm}$ at the top and $5 \mathrm{~mm}$ at the bottom part of the orifice. The air flows upward through the bed, causing the solid particles to be suspended. If the inlet air is disabled, the bed may settle onto the plate. The air was supplied by the compressor and was preheated before entering the gasifier.

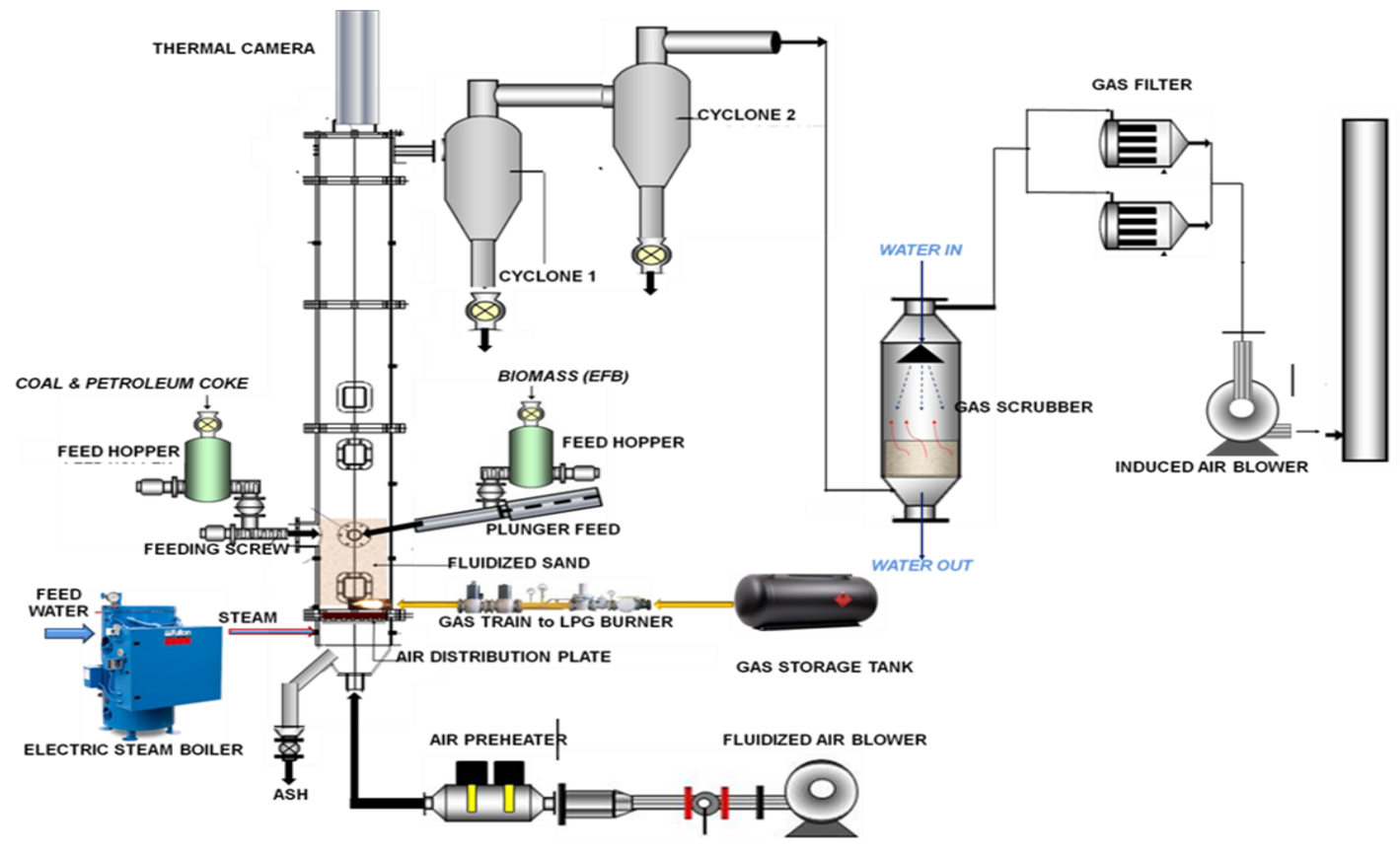

Figure 1. Schematic diagram of $150 \mathrm{~kW}_{\text {th }}$ pilot scale fluidized bed gasifier. 


\section{Experimental Procedure}

Before the start-up, about $15 \mathrm{~kg}$ (equivalent to static bed height of $150 \mathrm{~mm}$ ) of silica sand was placed on top of the gasifier bed. The air flow was preheated before entering the distributor plate. Air was continuously supplied, in order to create fluidizing of a bubbling condition inside the gasifier. Before entering the air distributor plate, the flow rate of the air was controlled using an air flow meter and heated to $100^{\circ} \mathrm{C}$ using an electric heater. Liquefied pressurised gas (LPG) with a gas burner was used to increase the bed temperature to $400^{\circ} \mathrm{C}$. Then, it was turned off once the fuel was continuously fed into the gasifier bed. The bed temperature increased to the desired temperature with the continuous supply of fuels. The feed rate of the coal and petcoke was measured using a screw-feeder controller. The bed temperature was controlled to be isothermal at $700-800^{\circ} \mathrm{C}$. The equivalence ratio (ER), which is the ratio of air and fuel flow rate for all experiments, was maintained at 0.31 . This was to ascertain that the fluidizing and gasification process was stable inside the reactor bed. The producer gas leaving the freeboard section was passed through two cyclones to trap entrained particles. The raw gas was cleaned by a gas cleaning system and finally filtered by an activated carbon filter before the gas was released through the chimney.

Product gases were sampled in 3 location of the gasifier's freeboard, first before the cyclones, secondly after the cleaning system and finally after the activated carbon filter. The produced gas started to be released after about 25-30 minutes from the starting of coal feeding at the steady state of the bed temperature within $700-800{ }^{\circ} \mathrm{C}$, and it was sampled using online gas chromatography (GC). The GC was fitted with a Molecular Sieve 5A column and Porapak Q column, with helium gas as the carrier gas, to detect the produced gases. Two detectors were used: a flame ionization detector (FID) for the analysis of the hydrocarbons and a thermal conductivity detector (TCD) for permanent gas analysis. All the results in these experiments are from the producer gas at the gasifier freeboard.

To access the process technology, the following variables were defined and determined:

- Producer gas composition, which is $\mathrm{H}_{2}, \mathrm{O}_{2}, \mathrm{~N}_{2}, \mathrm{CH}_{4}, \mathrm{CO}, \mathrm{CO}_{2}, \mathrm{C}_{2} \mathrm{H}_{2}, \mathrm{C}_{2} \mathrm{H}_{4}$ and $\mathrm{C}_{2} \mathrm{H}_{6}$

- Low heating values of the producer gas were calculated using Equation (3.3) from Skoulou et al. [10] as Eq. (1):

$$
L H V_{\text {gas }}=\left[(30 \times C O)+\left(25.7 \times \mathrm{H}_{2}\right)+\left(85.4 \times \mathrm{CH}_{4}\right)+\left(151.3 \times \mathrm{C}_{y} \mathrm{H}_{x}\right)\right] \times 4.2{\mathrm{~kJ} / \mathrm{Nm}^{3}}^{3}
$$

where $\mathrm{CO}, \mathrm{H}_{2}, \mathrm{CH}_{4}$ and $\mathrm{C}_{\mathrm{y}} \mathrm{H}_{\mathrm{x}}$ are the mol\% of those components in the gasification gas.

- Carbon conversion efficiency is calculated from equation below:

$$
\text { Carbon conversion }=\frac{\text { Carbon content in producer gas }}{\text { Carbon content in feedstock }}
$$




\section{RESULTS AND DISCUSSION}

Carbon monoxide, $\mathrm{CO}$; carbon dioxide, $\mathrm{CO}_{2}$; hydrogen, $\mathrm{H}_{2}$; oxygen, $\mathrm{O}_{2}$; nitrogen, $\mathrm{N}_{2}$; methane, $\mathrm{CH}_{4}$; ethylene, $\mathrm{C}_{2} \mathrm{H}_{4}$; ethane, $\mathrm{C}_{2} \mathrm{H}_{6}$; and acetylene, $\mathrm{C}_{2} \mathrm{H}_{2}$ were released during the gasification process. The producer gas composition of different fuel blends is listed in Table 2. $\mathrm{H}_{2}, \mathrm{CO}, \mathrm{CH}_{4}$ and $\mathrm{CO}_{2}$ showed a higher content than the other gaseous components. $\mathrm{N}_{2}$ contents were the highest due to the use of air in the feeding system. Table 2 shows that the overall process performance of coal-petcoke gasification depends on the percentage of petcoke in the feed, which varied between $0-100 \%$. Table 2 indicates that hydrogen gas produced for Adaro coal $(38.35 \mathrm{~mol} \%)$ is higher than that produced by petcoke $(4.26 \mathrm{~mol} \%)$. The fuel blend results show that there is only a slight decrease in the gas composition and the low heating value of the producer gas when $10 \%$ of petcoke is present in the blend $\left(\mathrm{H}_{2}\right.$ at $\left.37.7 \mathrm{~mol} \%\right)$. However, as the amount of petcoke in the fuel blend increased, the low heating value decreased tremendously. The lowest heating value was observed when the weight fraction of the coal and petcoke was the same (50:50). However, the low heating value started to increase when $70 \%$ petcoke was used in the study and it continued to increase when $100 \%$ petcoke was used. The increase in the petcoke ratio in fuel blends gave a reverse trend for methane content, whereby the amount of methane released increases at $20 \%$ and $40 \%$ petcoke in the fuel blends as compared to the $100 \%$ Adaro. The amount of heavier hydrocarbon contents in this study were found to be quite low and do not represent any trend.

Table 2. Producer gas composition of different fuel blends

\begin{tabular}{lcccccc}
\hline $\begin{array}{l}\text { Producer } \\
\text { gas comp. } \\
(\text { mol\% })\end{array}$ & $(100: 0)$ & $(90: 10)$ & $(60: 40)$ & $(50: 50)$ & $(30: 70)$ & $(0: 100)$ \\
\cline { 2 - 7 } & 38.35 & 37.7 & 21.89 & 5.74 & 2.28 & 4.26 \\
\hline $\mathrm{H}_{2}$ & 4.92 & 4.28 & 2.2 & 0.22 & 1.27 & 0.61 \\
$\mathrm{CO}$ & 0.29 & 0.44 & 7.88 & 15.78 & 8.64 & 6.57 \\
$\mathrm{O}_{2}$ & 6.92 & 6.53 & 4.57 & 2.82 & 7.09 & 8.43 \\
$\mathrm{CO}_{2}$ & 0.84 & 1.14 & 1.16 & 0.1 & 0.41 & 0.67 \\
$\mathrm{CH}_{4}$ & 0.14 & 0.17 & 0.13 & 0 & 0.11 & 0.02 \\
$\mathrm{C}_{2} \mathrm{H}_{4}$ & 0.01 & 0.01 & 0.02 & 0 & 0.01 & 0 \\
$\mathrm{C}_{2} \mathrm{H}_{6}$ & 0.01 & 0 & 0.01 & 0 & 0.01 & 0 \\
$\mathrm{C}_{2} \mathrm{H}_{2}$ & & & & & & 0 \\
\hline
\end{tabular}

Figure 2 shows the effect of the petcoke composition in the blend on the composition of syngas $\left(\mathrm{CO}, \mathrm{CO}_{2}, \mathrm{H}_{2}\right.$, and $\left.\mathrm{O}_{2}\right)$. It can be seen that concentrations of both $\mathrm{H}_{2}$ and $\mathrm{CO}$ decrease with an increase in the petcoke composition in the fuel blend. This result contradicts the observation by Fermoso et al. (2009), where a positive synergy was discovered between the component blends. They found a slight increase in the amount of syngas production as the amount of petcoke increased. This may be attributed 
to the type of gasifier used by Fermoso et al. (2009), which is an entrained flow gasifier at $1.5 \mathrm{MPa}$ pressure, $1000^{\circ} \mathrm{C}$ temperature, with the gasifying agent being a combination of oxygen and steam. The composition of $\mathrm{O}_{2}$ is highest when the weight fraction of coal and petcoke is equal (50:50). In the gasification process, $\mathrm{O}_{2}$ is needed to convert carbon in the feedstock to gas. Therefore, this result shows that at 50:50 coal:petcoke blend, the minimum gasification process took place as indicated by the maximum amount of $\mathrm{O}_{2}$ in the syngas. Unconsumed $\mathrm{O}_{2}$ in the system will be released in the syngas.

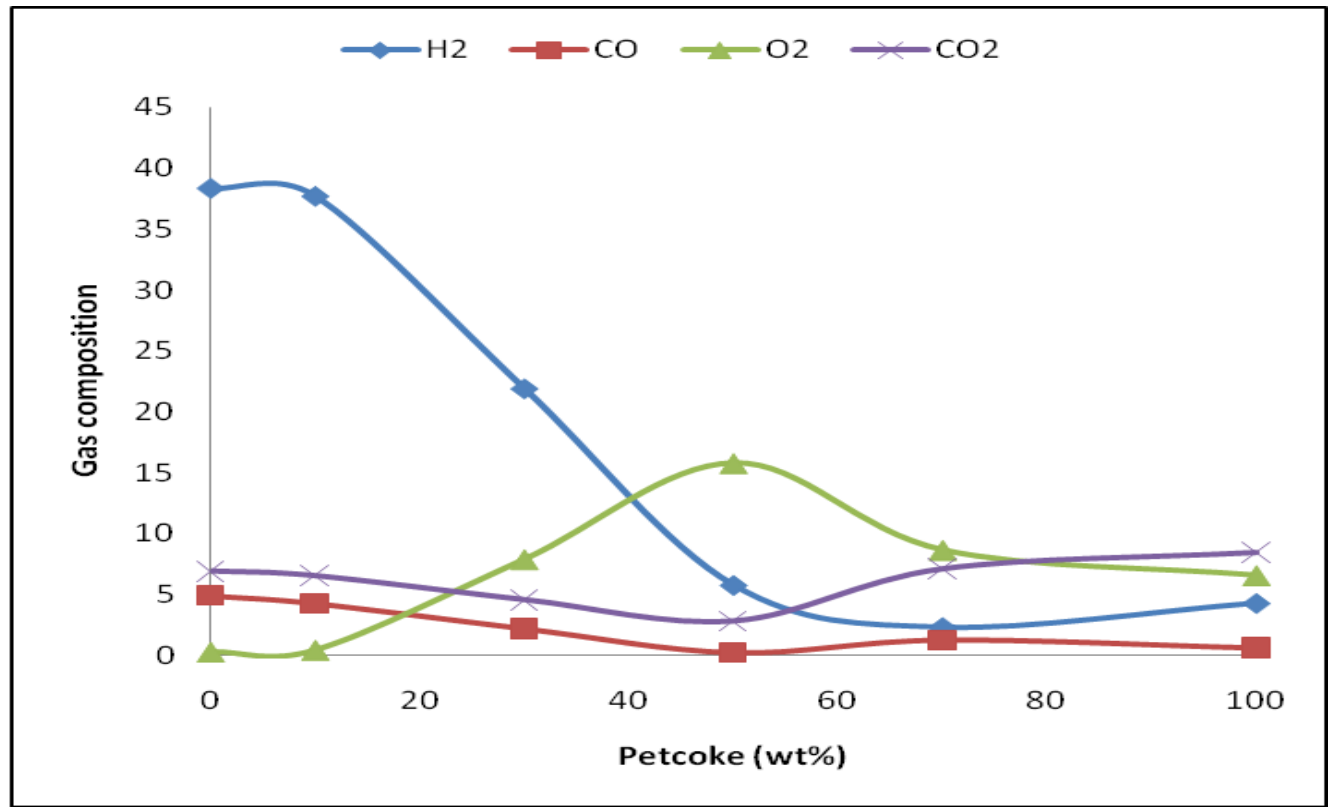

Figure 2. Effect of petcoke \% on the composition of syngas

Figure 3 shows the effect of the petcoke percentage in the blend on the carbon conversion efficiency. As can be seen from Figure 3, the carbon conversion efficiency decreased as the petcoke percentage increased up to a petcoke percentage of around 50 $\%$ in the blend, then again started to increase. This is similar to the study by Fermoso et al., (2009), who found that the carbon conversion decreases with the increase in petcoke content due to its lower reactivity compared to coal. However, from Figure 3, it is also observed that the conversion efficiency of $100 \%$ petcoke is very much lower than that of $20 \%$ petcoke. This indicates that there is a synergistic interaction between coal and petcoke during the gasification process. Lee et al, (2010) encountered a similar result in their study of a petcoke and coal slurries mixture in an entrained flow gasifier.

Figure 4 shows the effect of petcoke addition on the low heating value of the producer gas in co-gasification of coal-petcoke. Similar to Figure 2 and Figure 3, the low heating value decreases with the increase in petcoke ratio in the fuel blends, up to about $50-60 \%$ coal. However, the value starts to increase when more than $60 \%$ of petcoke is incorporated in the blend. Again, similar to Figure 2, this may be attributed to the low reactivity of petcoke. The increase in the low heating value after $60 \%$ petcoke addition may be due to the fact that all the coal was already gasified and petcoke gasification was starting to take place. 


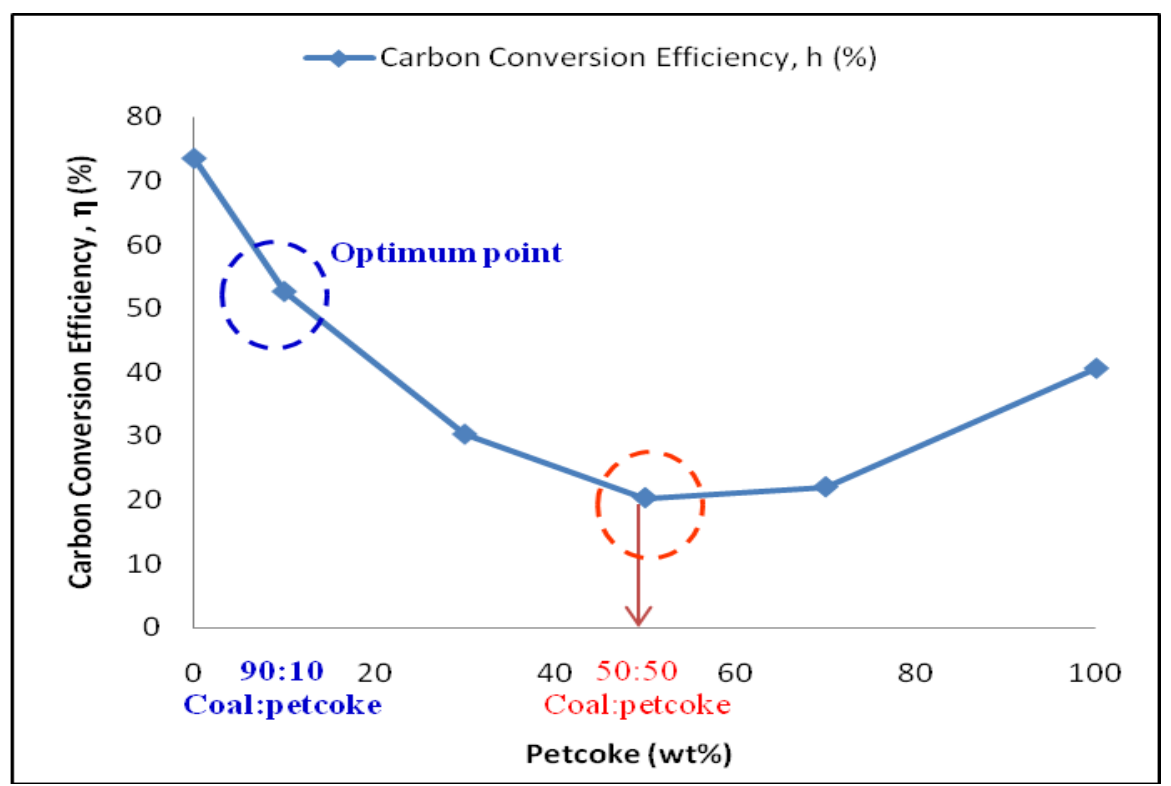

Figure 3. Effect of petcoke percentage in the blend on the carbon conversion efficiency.

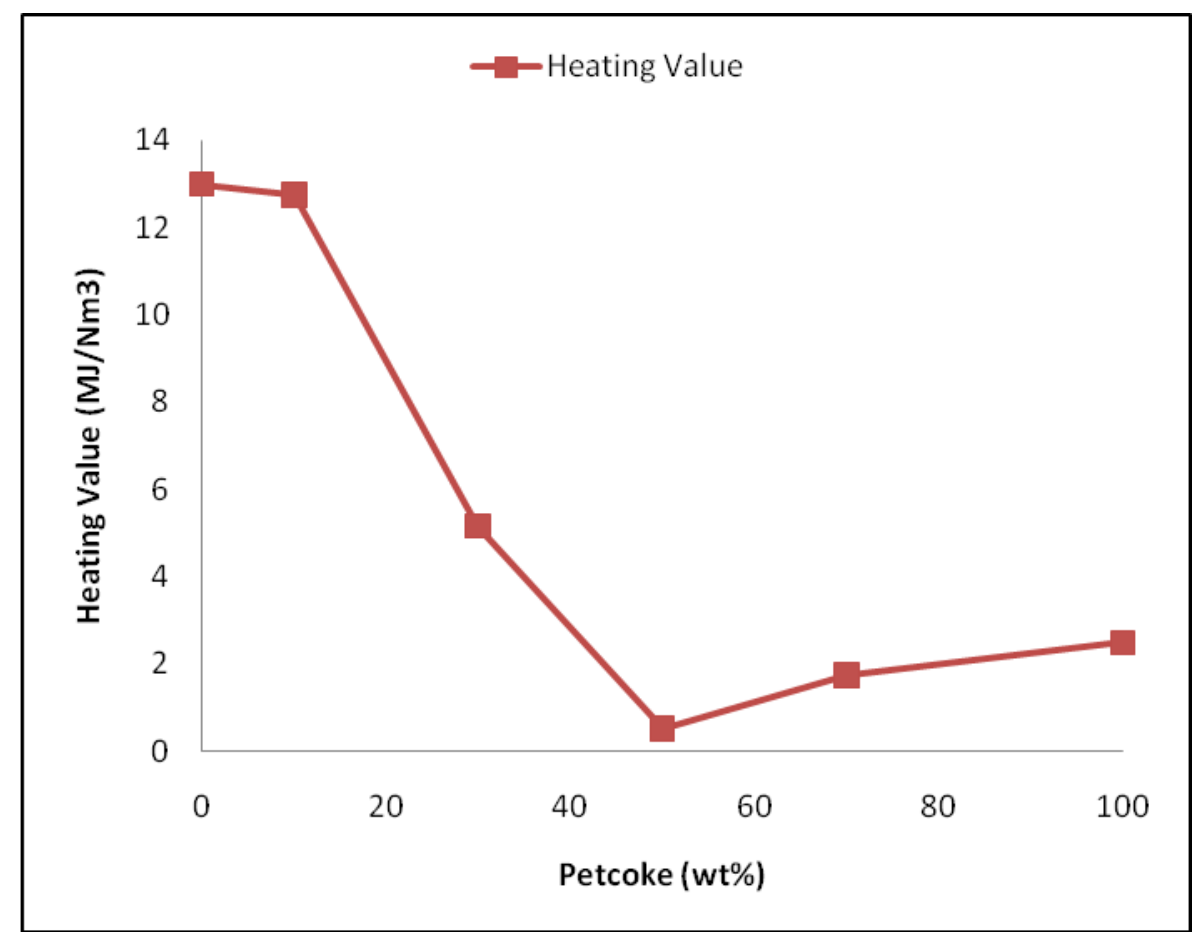

Figure 4. Effect of fuel blends on the low heating value of producer gas.

Volatile matter content contributes to the reactivity of a solid fuel and its conversion to char inside the gasifier. Fuels with higher volatile matter content are more reactive and can therefore be converted more easily into gas. From the proximate and ultimate analysis result in Table 1 , the volatile matter of petcoke $(10.4 \%)$ is lower than the Adaro coal (46.5\%). Oxygen $\left(\mathrm{O}_{2}\right)$ is needed in the gasification process to convert carbon in the feedstock to hydrocarbons $\left(\mathrm{C}_{\mathrm{n}} \mathrm{H}_{\mathrm{m}}\right)$ and hydrogen $\left(\mathrm{H}_{2}\right)$. Initially, all $\mathrm{O}_{2}$ is consumed mainly by coal due to its low reactivity, resulting in a very low conversion of petcoke. Thus, as the amount of petcoke in the blend is increased, overall gasification 
efficiency is reduced. As the percentage of petcoke in the feed was more than $50 \%$, all the coal in the blend started to be almost wholly converted without using all the $\mathrm{O}_{2}$ in the system. More $\mathrm{O}_{2}$ was then available for petcoke gasification. Thus carbon conversion, LHV and gas composition started to increase again. These phenomena explain the results obtained in Table 2 and Figure 2-4. This finding is supported by previous researchers (Goyal, Pushpavanam, and Voolapalli, 2010), who found that combining different fuels (bituminous coal and petcoke) as gasifier feed can influence the efficiency of the gasification process.

\section{CONCLUSION}

Gasification experiments on coal, petcoke and coal-petcoke blends in the atmospheric fluidized bed gasifier were performed. The characteristics of the producer gas, carbon conversion efficiency, syngas composition and low heating value were determined and compared. The lower heating values are $5.16 \mathrm{MJ} / \mathrm{Nm}^{3}$ for $100 \%$ coal and $0.79 \mathrm{MJ} / \mathrm{Nm}^{3}$ for $100 \%$ petcoke. In the case of fuel blends, the low heating values are 5.15, 3.16, 0.11 and $0.64 \mathrm{MJ} / \mathrm{Nm}^{3}$ for $20,40,50$ and $70 \%$ petcoke respectively. It has also been observed that, at the low heating value, the carbon conversion efficiency and syngas content show a minimum value at $50-60 \%$ petcoke in the fuel blend. On the other hand, the conversion efficiency and syngas composition start increasing after the petcoke percentage increases beyond $60 \%$. In conclusion, as far as the mixture of coal and petcoke is concerned, the optimum gasification efficiency was obtained at a 90:10 coal: petcoke blend. The lowest heating value was observed when the mixture was at 50:50. Therefore this mixture needs to be avoided when gasifying coal-petcoke blend. These results indicate that, due to the synergistic interactions between coal and petcoke blends, it is possible to gasify coal-petcoke blends in an atmospheric fluidized bed gasifier.

\section{ACKNOWLEDGMENT}

This work was carried out with financial support from the TNBR Seeding Fund project R-C-SF-0049-12-004-1. The contribution from the TNBR gasification team is acknowledged. Appreciation is extended to TNBR management and Tenaga Nasional Berhad for good support and assistance.

\section{REFERENCES}

Andre, R. N., Pinto, F., Franco, C., Dias, M., Gulyurtlu, I., Matos, M., \& Cabrita, I. (2005). Fluidized bed co-gasification of coal and olive oil industry wastes. Fuel, 84, 1635-1644.

Basu, P. (2006). Combustion and gasification in fluidized beds. CRC Press.

Fermoso, J., Arias, B., Plaza, M., Pevida, C., Rubiera, F., Pis, J., García-Peña, F., \& Casero, P. (2009). High-pressure co-gasification of coal with biomass and petroleum coke. Fuel Processing Technology, 90, 926-932.

Goyal, A., Pushpavanam, S., \& Voolapalli, R. K. (2010). Modeling and simulation of co-gasification of coal and petcoke in a bubbling fluidized bed coal gasifier. Fuel Processing Technology, 91(10), 1296-1307.

Harris, D. J., Roberts, D. G., \& Henderson, D. G. (2006). Gasification behavior of Australian coals at high temperature and pressure. Fuel, 85, 134-142. 
Lee, S. H., Yoon, S. J., Ra, H. W., Son, Y. I., Hong, J. C., \& Lee, J. G. (2010). Gasification characteristics of coke and mixture with coal in an entrained-flow gasifier. Energy, 35(8), 3239-3244.

Li, K., Zhang, R., \& Bi, J. (2010). Experimental study on syngas production by cogasification of coal and biomass in a fluidized bed. International Journal of Hydrogen Energy, 35, 2722-2726.

Mastellone, M. L., Zaccariello, L., \& Arena, U. (2010). Co-gasification of coal, plastic waste and wood in a bubbling fluidized bed reactor. Fuel, 89, 2991-3000.

Nagpal, S., Sarkar, T. K., \& Sen, P. K. (2005). Simulation of petcoke gasification in slagging moving bed reactors. Fuel Processing Technology, 86, 617-640.

Pinto, F., Franco, C., Neto Andre, R., Tavares, C., Dias, M., Gulyurtlu, I., \& Cabrita, I. (2003). Effect of experimental conditions on co-gasification of coal, biomass and plastics wastes with air/steam mixtures in a fluidized bed system. Fuel, 82, 1967-1976.

Skoulou, V., Koufodimos, G., Samaras, Z., \& Zabanitou, A. (2008). Low temperature gasification of olive kernels in a $5 \mathrm{~kW}$ fluidized bed reactor for $\mathrm{H} 2$ rich producer gas. International Journal of Hydrogen Energy, 33, 6515-6524.

Sofia, D., Coco Llano, P., Gioiano, A., Hernandez, M. I., Peña, F. G., \& Bar, D. (2013). Co-gasification of coal-petcoke and biomass in the Puertollano IGCC power plant. Chemical Engineering Research and Design, In Press (accessed on 16 January 2014), ISSN 0263-8762.

Taba, L. E., Irfan, M. F., Daud, W. M. A. W, \& Chakrabarti, M. H. (2012). The effect of temperature on various parameters in coal, biomass and co-gasification: A review. Renewable and Sustainable Energy Reviews, 16(8), 5584-5596. 